Андрій Зельницький, кандидат педагогічних наук, професор ORCID ID 0000-0002-3910-7329

Олег Рибчук

ORCID ID 0000-0003-3966-8326 Національний університет оборони України імені Івана Черняховського

\title{
ВИКЛАДАЧІ СПЕЦАЛЬНИХ ДИСЦИПЛІН ВВНЗ: СТАН ПІДГОТОВЛЕНОСТІ ТА НАПРЯМИ ЇЇ УДОСКОНАЛЕННЯ
}

Статтю присвячено висвітленню результатів емпіричного дослідження стану підготовленості викладачів спеціальних дисциплін ВВНЗ. Дослідження проводилося шляхом аналізу наукових досліджень та нормативно-правових документів, щзо визначають вимоги до підготовленості викладача вищої школи; порівняння фактів $i$ поглядів на досліджувану проблему в історичному контексті із сучасним ї̈ станом; анкетування, бесід, спостереження, експертних оцінок, самооцінювання, тестування; прогнозування умов та напрямів ефективного впровадження системи принципів, правил, вимог, які направляють пізнавальну діяльність викладачів. Новизна полягає в отриманні статистичних даних, щзо дало змогу встановити пріоритетні напрями для удосконалення системи підвищення кваліфікації науково-педагогічних працівників. За результатами дослідження такими визначено: ознайомлення викладачів із сучасними освітніми концепціями, теоріями, підходами; підготовка в напрямку організації наукових досліджень, а також із питань педагогічного діагностування.

Ключові слова: викладач спеціальних дисциплін; підготовленість; освітня діяльність.

Постановка проблеми. Визначальне місце в системі військової освіти займає військовий педагог. Саме через його діяльність реалізується воєнна державна політика, спрямована на зміцнення інтелектуального й духовного потенціалу збройних сил, розвиток військової науки і техніки, збереження та примноження військових традицій. Тому нині перед національною вищою військовою школою стоїть завдання підготувати таких науково-педагогічних фахівців, які могли б у своїй педагогічній діяльності поєднувати глибокі фундаментальні військово-професійні знання, практичний досвід i педагогічну підготовленість із постійно зростаючими вимогами сучасного суспільства до Збройних Сил України та системи вищої військової освіти. Вимоги до викладача вищої школи конкретизуються в низці програмних та нормативних документів, зокрема: Національній доктрині розвитку освіти України у XXI ст. (2002), Законі України «Про вищу освіту» (2014), Законі України «Про освіту» (2017).

3 огляду на зазначене, проблема підготовки військових педагогів, насамперед, у системі післядипломної освіти набуває особливого значення.

3 метою з'ясування актуальних проблемних питань підготовленості викладачів спеціальних дисциплін ВВНЗ до педагогічної діяльності нами було проведено емпіричне дослідження у провідних військових вишах країни. 
Аналіз останніх досліджень і публікацій. Проблему професійного становлення й розвитку особистості педагога вивчали С. Гессен, С. Гончаренко, О. Дубасенюк， I. Зимня, І. Зязюн, В. Кремень, Н. Кузьміна, Н. Ничкало, О. Пєхота, С. Сисоєва та ін. Питанням підготовки військових педагогів та удосконалення їх педагогічного фаху присвячені праці А. Вітченка, Ю. Красильника, М. Нещадима, В. Осьодла, Ю. Приходька, В. Ягупова та ін.

Для визначення напрямів дослідження слушною вважаємо думку вчених: «Свідченням високого рівня сформованості педагогічної культури $€$ гуманістична спрямованість особистості педагога, психолого-педагогічна компетентність і розвинуте педагогічне мислення, володіння педагогічними технологіями, досвід творчої діяльність, уміння обгрунтувати власну педагогічну діяльність як систему (дидактичну, виховну, методичну), культура професійної поведінки (педагогічне спілкування, мова, зовнішній вигляд)» [1, с. 44].

А. Вітченко та В. Осьодло вважають: «...На шляху реалізації триєдиної освітньо-виховної мети майбутній викладач ВВНЗ має осягнути особливості професійного навчання, виховання та управління військовим вишем, навчитися планувати, організовувати, контролювати результативність освітнього процесу, набути досвіду керування навчально-пізнавальною, науково-дослідницькою, виховною діяльністю студентів, курсантів, слухачів...» [2, с. 24]. Зазначене дає змогу уточнити зміст досліджуваного явища.

Важливою для нашого дослідження є позиція В. Ягупова, який зазначає: «...за наявності певної військово-професійної підготовленості, психологопедагогічної компетентності, розвинутих особистісних властивостей кожен військовий педагог може досягти позитивних результатів у навчанні, вихованні та психологічній підготовці військовослужбовців» [5, с. 306]. Зазначене вказує на доцільність перепідготовки й підвищення кваліфікації військових керівників для подальшої педагогічної діяльності.

Незважаючи на значну кількість грунтовних досліджень, аналіз наукових праць, присвячених підготовці викладачів вищої школи та військових викладачів, засвідчив надзвичайну актуальність і проблемність цього напряму досліджень. Зокрема визначення сучасного стану підготовленості військових викладачів до педагогічної діяльності у ВВНЗ не стало предметом окремого педагогічного дослідження.

Мета статті - на основі аналізу проведеного дослідження визначити нагальні проблеми в підготовленості викладачів спеціальних дисциплін ВВНЗ та запропонувати основні напрями їі удосконалення.

Методи дослідження. Теоретичні: аналіз наукових досліджень та нормативно-правових документів, що визначають вимоги до підготовленості викладача вищої школи; порівняння фактів і поглядів на досліджувану проблему в історичному контексті із сучасним іï станом; прогнозування - для 
виявлення умов та напрямів ефективного впровадження системи принципів, правил, вимог, які направляють пізнавальну діяльність викладача.

Емпіричні: анкетування, бесіда, пряме й непряме спостереження, метод експертних оцінок, самооцінювання, тестування - для вивчення сформованості фахової компетентності викладачів спеціальних дисциплін BBH3.

Викладення основного матеріалу. В основу дослідження було покладено вимоги, що висуваються до рівня підготовленості викладачів вищої школи відповідними нормативними документами, результатами фундаментальних педагогічних досліджень, а також розробленою авторською моделлю розвитку фахової компетентності викладачів ВВНЗ у системі післядипломної освіти [3, с. 231-236].

Методика проведення педагогічного дослідження розвиненості фахової компетентності викладачів ВВНЗ описана в наших попередніх дослідженнях [4, с. 53-58].

У проведеному емпіричному дослідженні взяли участь 267 викладачів ВВНЗ, що дало змогу нам говорити про репрезентативність вибірки й високий рівень достовірності отриманих результатів.

За допомогою опитування встановлено, що актуальною проблемою для ВВН3 залишається недостатній рівень психолого-педагогічної підготовленості науково-педагогічних працівників, а саме: тільки 17 \% опитаних мають педагогічну освіту, близько 29 \% - науковий ступінь, у понад $46 \%$ - педагогічний стаж до 5 років. Варто також зазначити, що близько 70 \% викладачів вказали на те, що вони відчувають потребу в удосконаленні власної педагогічної компетентності.

При цьому значна кількість опитаних (близько 73 \%) вказали на високу мотивованість і захопленість педагогічною діяльністю, 55 \% відзначили, що отримують задоволення від своєї роботи зі слухачами (курсантами). Це дає підстави вважати, що потенціал для розвитку педагогічної компетентності викладачів ВВНЗ є високим, оскільки гуманістичний світогляд, позитивне ставлення до вихованців та висока мотивація до педагогічної діяльності $\epsilon$ надійною основою для розвитку й саморозвитку важливих професійних якостей військових педагогів.

Опитування проводилося шляхом самооцінювання із застосуванням розроблених анкет. У них пропонувалося оцінити власний рівень розвиненості компетентності за основними напрямами педагогічної діяльності викладача ВВН3, використовуючи 4-бальну подрібнену шкалу (від 2 до 5) з поділкою 0,25 бала.

Перехід від бальної оцінки до рівнів розвиненості педагогічної компетентності здійснювався шляхом віднесення опитаних до таких рівнів:

базовий - від 2 до 3,75 бала;

достатній - від 3,75 до 4,5 бала;

високий - від 4,5 до 5 балів. 
Опитування дало змогу встановити напрями діяльності військового викладача, потребу вдосконалення 3 яких найбільш гостро відчувають респонденти, а саме: 3 організації наукових досліджень (оцінили власну компетентність із середнім балом 3,82) та у здійсненні педагогічного діагностування $(3,97)$ (рис. 1$)$.

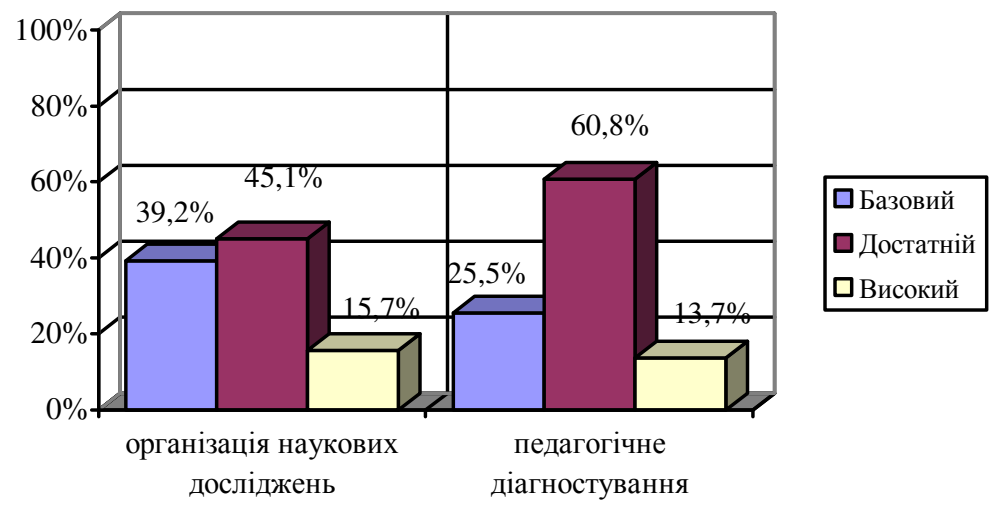

Рис. 1. Напрями викладацької діяльності, за якими проявився гранично низький рівень розвиненості компетентності

Найвищий рівень власної компетентності респонденти оцінили за напрямами: 3 дисципліни викладання $(4,46)$ та 3 методики викладання $(4,29)$ (рис. 2).

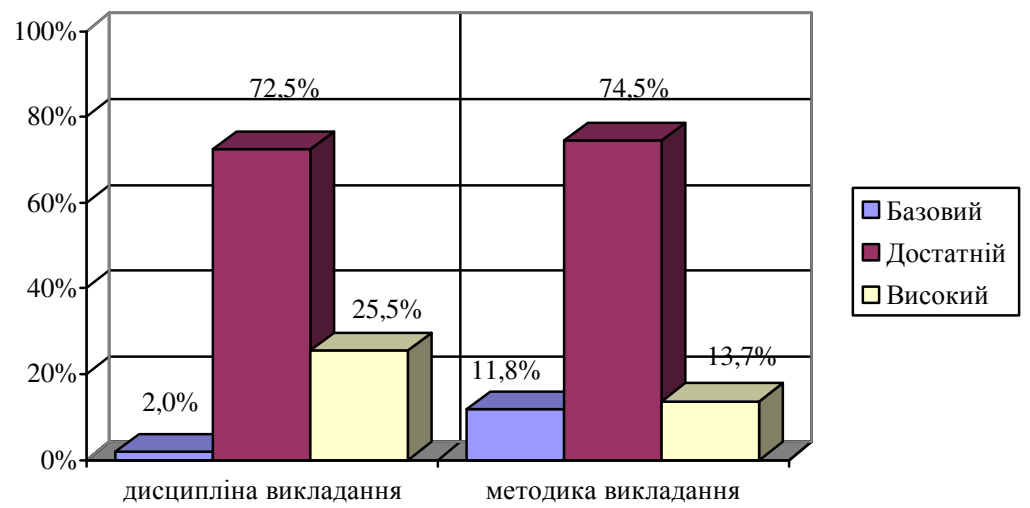

Рис. 2. Напрями викладацької діяльності, за якими проявився найбільш високий рівень розвиненості компетентності

До найбільш важливих результатів за підсумками анкетування варто віднести також отриманий рівень розуміння викладачами засад компетентнісного підходу та застосування основних його положень у педагогічній діяльності. Близько $46 \%$ опитаних основною метою своєї діяльності визначають передачу слухачам (курсантам) знань, формування в них відповідних навичок та вмінь, тобто зорієнтовані на реалізацію знаннєвого підходу в навчанні, що не відповідає сучасним вимогам до освітньої діяльності. Лише $12,5 \%$ досліджуваних спрямовують власну викладацьку діяльність на формування та розвиток здатностей до застосування отриманих знань і вмінь у практичній діяльності, $11 \%$ пріоритетом власної діяльності визначають розвиток слухачів (курсантів) як творчих особистостей, спроможних вирішувати складні, нестандартні 
професійні завдання в різних умовах, ще $23 \%$ мету своєї педагогічної діяльності вбачають у спонуканні курсантів до самоосвіти й саморозвитку.

Проведене дослідження вказало на брак знань і досвіду у здійсненні низки заходів, що притаманні викладацькій діяльності. Близько 88 \% опитаних викладачів відчувають недостатню підготовленість із питань підвищення мотивованості слухачів (курсантів), 86 \% - 3 упровадження положень компетентнісного підходу в освітній процес, 85 \% вказує на недостатню обізнаність щодо методології освіти, сучасних освітніх концепцій і теорій, $83 \%$ - стосовно організації зворотного зв'язку 3 випускниками для удосконалення навчального змісту, близько 81 \% педагогів відчувають труднощі з приводу впровадження міждисциплінарного підходу, близько 80 \% висловили бажання вдосконалити власну підготовку 3 таких питань: проектування проблемних ситуацій у навчанні; визначення індивідуально-психологічних особливостей слухачів (курсантів); упровадження інноваційного педагогічного досвіду, досвіду НАТО щодо підготовки військових фахівців; педагогічної кваліметрії (кількісного оцінювання якості освіти на критеріальній основі); активізації пізнавальної діяльності курсантів.

Вивчення умов, що сприяють здійсненню освітньої діяльності викладачами у ВВНЗ, дало змогу встановити ті з них, що мають пріоритетне значення для викладачів, проте не реалізуються в повному обсязі в освітньому процесі. Понад 45 \% науково-педагогічних працівників вказали на низький рівень мотивованості курсантів до навчання у ВВНЗ, близько $43 \%$ - на неоптимальні умови для здійснення науково-інноваційної діяльності, 42 \% не задоволені адміністративно-розпорядчими умовами у ВВН3 (вважають надмірним адміністрування діяльності викладача), 35 \% вважають, що матеріально-технічна база ВВНЗ потребує оновлення, близько 34 \% відзначили необхідність покращення самоврядних умов у ВВНЗ, підвищення ролі науково-педагогічних працівників у прийнятті рішень 3 управління освітньою діяльністю.

Висновки та перспективи подальших досліджень. Таким чином, комплексне дослідження рівнів підготовленості викладачів спеціальних дисциплін ВВНЗ до педагогічної діяльності дало змогу визначити низку нагальних проблем, що потребують теоретичного осмислення і на цій основі розроблення відповідних методичних рекомендацій.

На сьогодні, як свідчать результати проведеного дослідження, актуальною залишається проблема фахової підготовки викладачів ВВНЗ, вирішення якої вбачаємо в підвищенні їх кваліфікації в системі післядипломної освіти. Важливими напрямами підвищення кваліфікації викладачів ВВНЗ слід вважати такі, як: ознайомлення їх iз сучасними освітніми концепціями, теоріями, підходами; вивчення питань організації наукових досліджень, педагогічного діагностування. Вагомою позитивною передумовою вирішення зазначених проблем є високий рівень мотивованості 
науково-педагогічних працівників до викладацької діяльності та самоосвіти, про що зазначили 73 \% опитаних.

Перспективним напрямом подальшого дослідження $є$ відпрацювання методичних рекомендацій з удосконалення системи післядипломної освіти викладачів ВВНЗ.

\section{ЛІТЕРАТУРА}

1. Військова психологія та педагогіка: інноваційний підхід: у 2 ч. Ч. 2: підручник / [Ю. С. Красильник, Г. О. Верхоланцев, Л. І. Карпова-Чемерис та ін.] - К. : НУОУ ім. Івана Черняховського, 2013. - $336 \mathrm{c.}$

2. Вітченко А. О., Осьодло В. І. Педагогіка вищої військової школи : підручник / А. О. Вітченко, В. І. Осьодло. - К. : НУОУ ім. Івана Черняховського, 2017. - 504 с.

3. Рибчук О.О. Педагогічна модель розвитку фахової компетентності викладачів ВВН3 у системі післядипломної освіти / О. О. Рибчук // Вісник Житомирського державного університету імені Івана Франка : науковий журнал Педагогічні науки, Вип. 2 (88). - Житомир. : ЖДУ імені Івана Франка, 2017 р.- С. 231-236.

4. Рыбчук О.О. Методика педагогического исследования проблемы развития специальной компетентности преподавателей вузов в системе последипломного образования / О. О. Рыбчук // «Педагогическое мастерство» Научно-теоретический и методический журнал, № 1. - Бухара. : Бухарский государственный університет, 2017 р. C. 53-59.

5. Ягупов В. В. Військова дидактика : Навчальний посібник. - К. : «Київський університет», 2000. - 400 с.

\section{REFERENCES}

1. Viys'kova psykholohiya ta pedahohika: innovatsiynyy pidkhid: u 2 ch. Ch. 2 : pidruchnyk [Military Psychology and Pedagogy: an innovative approach] K. : NUOU im. Ivana Chernyakhovs'koho, 2013. - 336 s. (in Ukrainian).

2. Vitchenko A.O., Os'odlo V.I. (2017) Pedahohika vyshchoyi viys'kovoyi shkoly : pidruchnyk [Pedagogy of the Higher Military School: a textbook] K. : NUOU im. Ivana Chernyakhovs'koho,504 s. (in Ukrainian).

3. Rybchuk O.O. (2017) Pedahohichna model' rozvytku fakhovoyi kompetentnosti vykladachiv VVNZ u systemi pislyadyplomnoyi osvity [Pedagogical model of Higher Military Educational institutions lecturers professional competence development in the post-graduate education system] Visnyk Zhytomyrs'koho derzhavnoho universytetu imeni Ivana Franka : naukovyy zhurnal Pedahohichni nauky, Vyp. 2 (88). - Zhytomyr. : ZhDU imeni Ivana Franka,. 231-236. (in Ukrainian).

4. Rybchuk O.O. (2017) Metodika pedagogicheskogo issledovaniya problemy razvitiya specialnoy kompetentnosti prepodavateley vuzov $\mathrm{v}$ sisteme poslediplomnogo obrazovaniya [Higher military educational institutions lecturers special competence development pedagogical research methodology in postgraduate education system] «Pedagogicheskoe masterstvo» Nauchno-teoreticheskiy i metodicheskiy zhurnal, № 1. Buhara. : Buharskiy gosudarstvennyy universitet, 53-59. (in Russian).

5. Yahupov V.V. (2000) Viys'kova dydaktyka : Navchal'nyy posibnyk. [Military Didactics: Textbook] K. : «Kyyivs'kyy universytet», 400 s. (in Ukrainian). 


\title{
РЕЗЮМЕ
}

Андрей Зельницький, кандидат педагогических наук, профессор Олег Рыбчук, Национальный университет обороны Украины имени Ивана Черняховского

\section{Преподаватели специальных дисциплин ВВУЗ: состояние подготовленности и направления её совершенствования}

Статью посвящено освещению результатов эмпирического исследования состояния подготовленности преподавателей специальных дисциплин ВВУЗ. Исследование проводилось путем анализа научных исследований и нормативно-правовых документов, определяющих требования к подготовленности преподавателя высшей школь; сравнения фактов и взглядов на исследуемую проблему в историческом контексте с современным ее состоянием; анкетирования, бесед, наблюдения, экспертных оценок, самооченки, тестирования; прогнозирования условий и направлений эффекттивного внедрения системы принципов, правил, требований, которые направляют познавательную деятельность преподавателей. Новизна заключается в получении статистических данных, что позволило установить приоритетные направления для совершенствования системы повышения квалификачии научно-педагогических работников. По результатам исследования такими определены: ознакомление преподавателей $c$ современными образовательными конщепциями, теориями, подходами; подготовка по направлению организации научных исследований, а также по вопросам педагогического диагностирования.

Ключевые слова: преподаватель специальных дисциплин; подготовленность; образовательная деятельность.

\section{SUMMARY}

\author{
Andrii Zelnytskyi, \\ $\mathrm{PhD}$ (Education), professor, \\ Oleh Rybchuk, \\ named after Ivan Chernyahovskyi
}

National Defence University of Ukraine

\section{Special subject lecturers of higher military educational establishments: state of preparedness and directions for improvement}

Introduction: There is a task before the national higher military educational institutions to prepare the scientific pedagogical specialists, who could unite the deep fundamental military professional knowledge, practical experience and pedagogical excellence with constantly increasing challenges of modern society to the Armed Forces of Ukraine and military higher education system in their military activities. The pedagogical qualification system improvement stipulates the research of military teachers readiness for the pedagogical work modern state.

The purpose is to highlight the actual state, problematic issues and directions of improvement of higher military educational institutions special subjects lecturers preparedness.

Methods: theoreical: analysis of the theoretical: scientific researches and normative and legal documents, which determines the demands to the higher military school lecturers preparedness; views and facts comparison concerning the investigated topic in historical context with modern state; prognosis to determine the conditions and directions of effective implementation of the system of principles, rules, demands, which directs lecturers cognitive activities. 
Empirical: questionnaires, conversation, direct and indirect observation, experts assessment method, self-assessment, testing - were used with the aim of determining the level of higher military educational institutions special subjects lecturers professional competence formedness.

Results: The statistical data, obtained as a result of the research, permitted to determine the priority directions to improve the scientific pedagogical personnel postgraduate education system. These are: lecturers familiarization with modern education conceptions, theories, approaches, scientific investigation preparation and pedagogical diagnosing.

Originality: The complex investigation of the higher military educational institutions special subjects lecturers preparedness allowed to determine some drawbacks in their preparation, also as some suggestions concerning the directions of pedagogical qualification improvement and the problems in proper organization and pedagogical conditions provision of pedagogical activities in higher military educational institutions.

Conclusion: The problem of professional development of higher military educational institutions lecturers, the solving of which is seen in the professional development in the postgraduate education system by involving the teachers to the pedagogical qualification development courses and distance learning.

Key words: competence; military and professional competence; military lecturer; pedagogical activities; military and professional competence. 